\title{
Leituras antropológicas sobre a arte kadiwéu
}

Maria Raquel da Cruz Duran ${ }^{1}$

Universidade de Sáo Paulo, São Paulo, São Paulo, Brasil

DOI 10.11606/issn.2316-9133.v24i24p43-70

resumo Neste artigo, propomo-nos a entender como as análises da arte kadiwéu elaboradas por Guido Boggiani, Claude Lévi-Strauss e Darcy Ribeiro dialogam com duas vertentes teóricas da antropologia e com a minha própria experiência etnográfica, realizada entre as mulheres artistas kadiwéu da aldeia Alves de Barros, município de Porto Murtinho-MS. Partindo da compreensão do dualismo existente entre a arte como sistema de comunicação e a arte como agência, e servindo-nos das contribuiçôes dos autores supracitados e dos meus apontamentos etnográficos, pretendemos desenvolver um estudo da arte kadiwéu.

palavras-chave: Kadiwéu; Arte; Antropologia; Agência; Sistema de comunicação.

\section{Anthropological readings on kadiwéu art}

abstract In this article, we propose to understand how the analysis of kadiwéu art made by Guido Boggiani, Claude Levi- Strauss and Darcy Ribeiro dialogues with two theoretical schools of anthropology and with my own ethnography experience, conducted among kadiwéu women artists in the village of Alves de Barros, municipality of Porto Murtinho-MS. Starting by the understanding of the existing dualism between art as a communication system and art as agency, and making use of the contributions of the above mentioned authors and my ethnographic notes, we intend to develop a kadiwéu art study.

keywords Kadiwéu; Art; Anthropology; Agency; Communication system.

\section{Introdução}

Os Kadiwéu, que se autodeclaram Ejiwajegi, Eyigua-yegi, "povo da palmeira Eyiguá” (SANCHEZ-LABRADOR, 1910, p. 266-268), fazem parte de um dos subgrupos Guaikuru e, assim como estes, derivaram sua autodenominação de alguma característica de seu habitat. ${ }^{2}$ Esse povo ficou conhecido nacional e internacionalmente tanto por sua habilidade guerreira, destacável em sua participação na Guerra do Paraguai (1864 - 1870) - inspiração do famoso retrato de Debret de um guerreiro kadiwéu em seu cavalo $-{ }^{3}$ quanto pelas pinturas que aplicavam em diferentes superfícies. 
Ambas as características, de guerra e de arte, foram abordadas em obras de jesuítas, exploradores, militares, antropólogos e outros pesquisadores. ${ }^{4}$ Em se tratando de Kadiwéu, são consideradas clássicas as obras de Guido Boggiani (Os Caduveo, 1894), Claude Lévi-Strauss (Tristes trópicos, 1955) e Darcy Ribeiro (Kadiwéu, 1950), que tiveram seus encontros com os Kadiwéu em contextos muito diferentes.

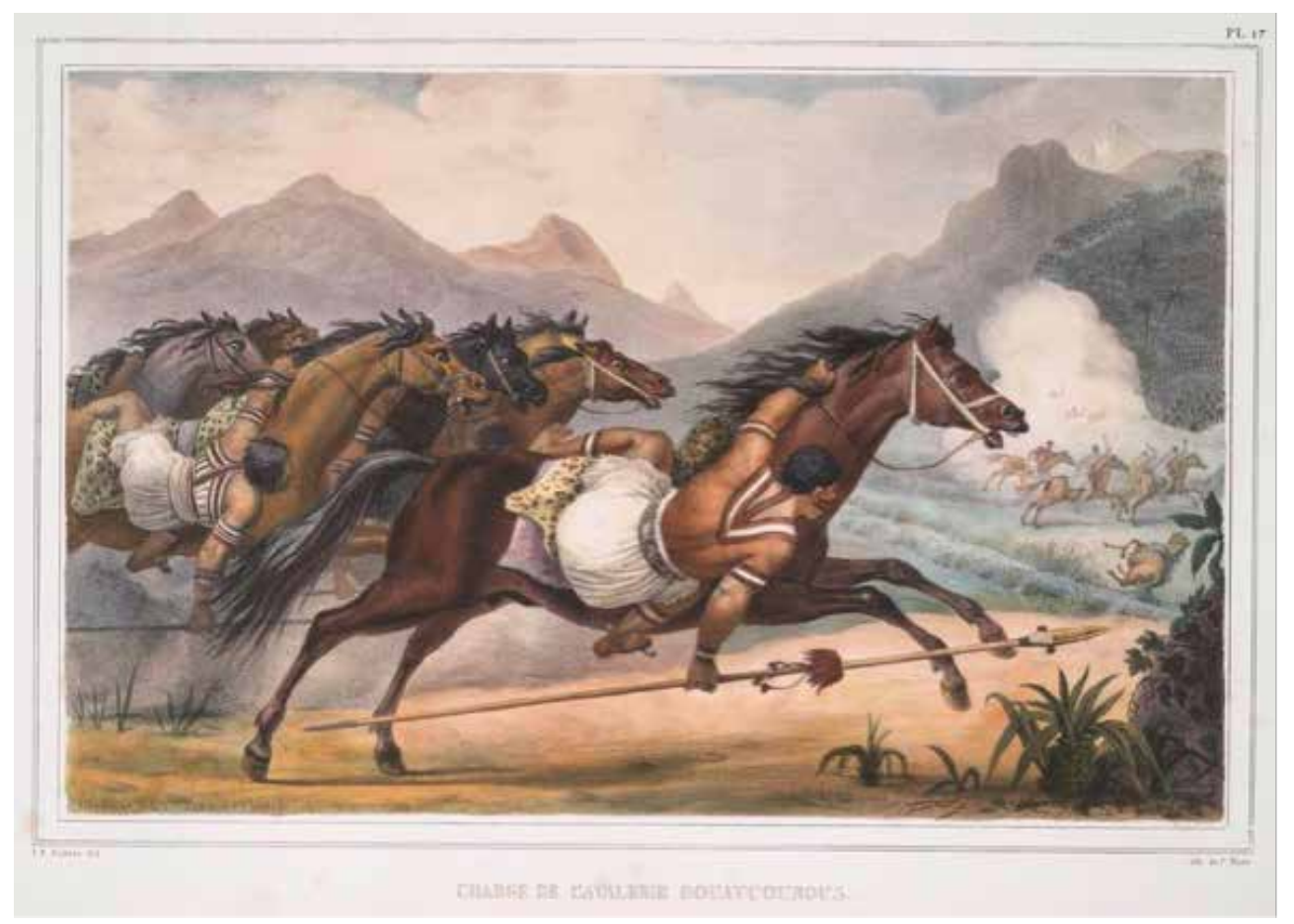

Figura 01 Charge de cavalerie Gouaycourous (In: DEBRET, 1975, p.17).

Severi e Lagrou (2013) assinalam como a antropologia, estudando a arte, passou de um enfoque interessado nos sistemas de comunicação que esta veicularia - em que o livro Grafismo indígena (VIDAL, 1992) é referência -, "para uma abordagem praxiológica onde se dá a centralidade da agência da imagem" (SEVERI; LAGROU, 2013, p.11) - sendo Art and Agency (Gell, 1999) seu expoente maior. Destarte, em um primeiro momento, explicitaremos as teorizaçóes sobre a arte kadiwéu apontadas pelos autores supracitados. Num segundo momento, faremos apontamentos sobre aquilo que temos observado em sete meses de trabalho de campo. ${ }^{5}$ Por fim, procederemos a uma crítica das relaçôes entre as etnografias e a teoria antropológica da arte. 


\section{A arte e os clássicos da etnografia Kadiwéu: Boggiani, Lévi-Strauss e Ribeiro}

Guido Boggiani nasceu em Novara, em 20 de setembro de 1861, e faleceu em Mato Grosso, regiáo do Chaco, em 7 de maio de 1902. Boggiani esteve entre os Kadiwéu em 1892, hospedado na aldeia Nalique durante dois meses, e no ano de 1896. Seu diário de viagem, publicado em 1894 , mostra um comerciante de couro sensível às artes e humanidades, encantado pelo modo de vida daquele grupo, cuja população era de cerca de duzentos habitantes, e que "[...] viveu como um Kadiwéu, vestiu-se como eles, casou-se temporariamente com uma mulher do grupo" (PECHINCHA, 2000, p. 154), estabelecendo relaçóes amistosas que perduraram na memória dos protagonistas deste encontro.

Claude Lévi-Strauss nasceu em Bruxelas, em 28 de novembro de 1908, e faleceu em Paris, em 30 de outubro de 2009. Entre os anos de 1935 e 1939, Lévi-Strauss lecionou sociologia na recém-criada Universidade de São Paulo, momento decisivo para o despertar do então filósofo para a vocação antropológica, que floresceu conjuntamente à escritura da obra Tristes trópicos, publicada em 1955 (PASSETI, 2008).

Nas poucas semanas, não especificando quantas, em que Lévi-Strauss esteve entre os Kadiwéu, encontrou uma população de pouco mais de duzentas pessoas, divididas em três aldeias (Nalique, Engenho e uma terceira, não nomeada), que lhe propiciaram uma descrição breve dos mesmos temas que Boggiani percorreu, incluindo o maior interesse pela arte.

Os vinte anos que separam o encontro com os Kadiwéu, em 1935, e a publicação do livro Tristes trópicos, em 1955, foram fundamentais para o modo como o livro foi escrito, em que apresentava o auxílio da ciência antropológica na compreensão do emaranhado de informações coletadas anos antes, mantendo assim, nessa obra, o modelo de um diário de viagem.

Estabelecido na aldeia de Engenho, Lévi-Strauss elucida muitas atividades dos Kadiwéu, entre as quais: a caça, a coleta e a roça. Contudo, ao entender que o conjunto de costumes de um povo constrói um estilo próprio, de modo a formar sistemas, Lévi-Strauss elabora a ideia de que, entre os Kadiwéu, dualismos internos e externos representariam sua maneira particular de expressáo social, cultural, política, econômica, artística etc.

Darcy Ribeiro, nascido em Montes Claros no dia 26 de outubro de 1922, falecido em Brasília, no dia 17 de fevereiro de 1997, realiza trabalho de campo entre os Kadiwéu em 1947 e 1948. Esse trabalho frutifica na publicação do livro Kadiwéu: ensaios etnológicos sobre o saber, o azar e a beleza, cuja primeira edição é de 1950, sendo suas ponderações divididas em três grandes blocos: 1) "Mitologia: a busca do saber"; 2) "Religião: o controle do azar"; e 3) "Arte: a vontade da beleza". 
Com o propósito de "compreender os significados e funções dos mitos para apurar sua vinculação à cultura" (RIBEIRO, 1980, p. 25), Ribeiro fará uma antropologia em tom de salvamento, guiado pela percepção de decrepitude desse povo que naquele momento mantinha o número de habitantes descrito por Lévi-Strauss, mas se encontrava em uma crise de redefinição de seus valores. ${ }^{6}$

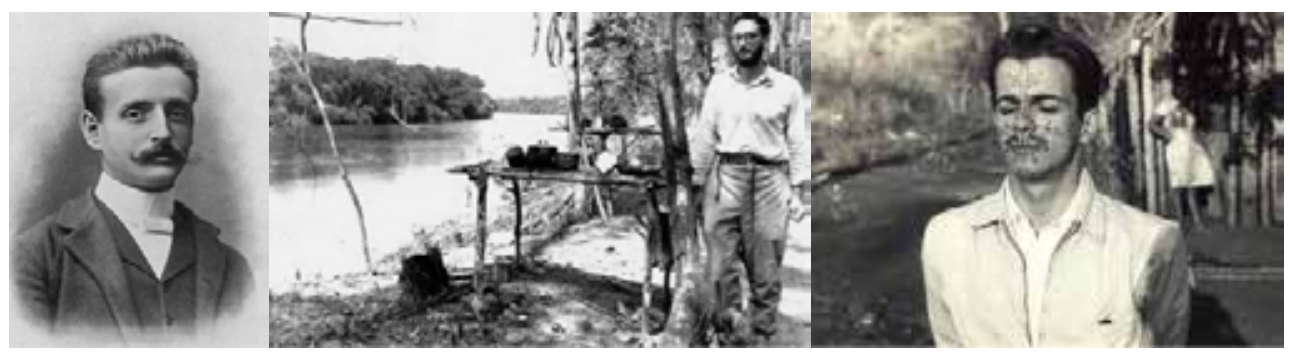

Figura 02 Guido Boggiani (In: Wikipedia. Disponível em: <https://en.wikipedia.org/ wiki/Guido_Boggiani>. Acessado em: 07/11/2015); Figura 03 (C) Levi-Strauss/Éditions PLON. Disponível em: <http://www2.cnrs.fr/en/1424.htm>. Acessado em: 27/09/2014); Figura 04 Darcy Ribeiro nos anos 1940 entre os Kadiwéu. Disponível em: <http://socialistamorena.cartacapital.com.br/mestico-e-bom-darcy-ribeiro/>. Acessado em: 27/09/2014.

De modo geral, os escritos destes autores sobre os Kadiwéu abarcam seu modo de vida, subsistência, educação, sexualidade, relaçóes sociais e políticas, religião, meio ambiente, mitos e ritos, entre outras temáticas, mas, sobretudo, a arte kadiwéu é posta em destaque. Após esta breve contextualização no tempo, nos acercaremos de cada um dos autores, individualmente, com o intuito de melhor descrever suas consideraçóes sobre o tema aqui em destaque.

Distribuídos em quatro aldeias (Nalique, Morrinho, Etóquija e Retiro), os duzentos Kadiwéu observados por Boggiani - que se tornariam, em 1939, apenas cem habitantes, pelo infanticídio e consumo excessivo do álcool, segundo Erich Freundt (RIBEIRO, 1980) - viviam em tolderias (casas tradicionais), dormiam em giraus (camas), transportavam-se por meio de catchibéus (canoas) e de bois, festejavam a moça e o novo capitáo (cacique), vestiam xiripás (tecidos usados como roupas), se divertiam em jogos de soco, recorriam à pajelança para curar suas doenças e à mitologia para compreender o mundo (BOGGIANI, 1945).

Por não exercer nenhuma função relativa ao Estado, o relato etnográfico de Boggiani sobre os Kadiwéu tem um valor particular. Interessado na compra de couros, especialmente de veados, o comerciante italiano retratou com suas tintas, tanto nas suas aquarelas quanto em seu diário, a abundância de animais silvestres como jabutis, veados, peixes e onças, das chuvas e mosquitos daquela regiáo do Gran Chaco, atualmente conhecida como Pantanal, delineando também a postura dos Kadiwéu e de seu líder Capitãozinho, no distribuir das atividades e da caça. 
Contudo, Boggiani fixou-se longamente no que mais o encantava naqueles índios, seus desenhos corporais, faciais e sua cerâmica. Descreveu pormenorizadamente os procedimentos de confecção e decoração da cerâmica, abarcando: o modo como a artista se posiciona; a forma como os padróes de pintura são impressos na cerâmica, sem treino e de memória; a maestria em dar contornos harmônicos para a peça; seu conhecimento em fazer estampas com a ajuda de pauzinhos, que esculpidos imprimem desenhos em superfícies repetidas vezes. Enfim, de modo geral, tudo nessa expressão artística o impressionou.

Nesse ínterim, podemos dizer que fora especialmente a pintura corporal e facial das mulheres kadiwéu - a disposição dos desenhos, das cores, das artistas e das modelos - aquilo que mais o atraiu nessa arte. Boggiani notou que a pintura do rosto e do corpo era feita pelas senhoras kadiwéu em suas cativas, ou entre elas mesmas, senhoras, dividindo seus rostos em duas metades que continham desenhos e cores diferentes, assemelhando-se aos arabescos dos bordados europeus. Ressaltou que existiam pinturas feitas somente em datas especiais, tais como as festas da moça, apreendendo que a mulher kadiwéu pintava-se de outra forma no período da puberdade. Mencionou também a diferença entre a tatuagem e a pintura que logo se apaga, embora essa análise não contenha muitos detalhes.

Além da aplicação da pintura facial/corporal que os senhores e os cativos utilizavam, e da pintura de cerâmicas, incluindo em ambos as decoraçóes com uso de miçangas, observou a disseminação da pintura em cavalos e objetos pessoais, que recebiam marcas de propriedade, ademais em tecidos, couros e abanicos. Convicto de que a arte kadiwéu era um modo de os espanhóis e portugueses, principais colonizadores da regiáo, valorizarem os conhecimentos indígenas como dignos de preservação, divulgação e civilidade, Boggiani exaltava tal característica como representativa do lugar do índio kadiwéu como um primitivo mais evoluído do que outros grupos da região, pensamento advindo do contexto científico dessa época, o evolucionismo cultural. 


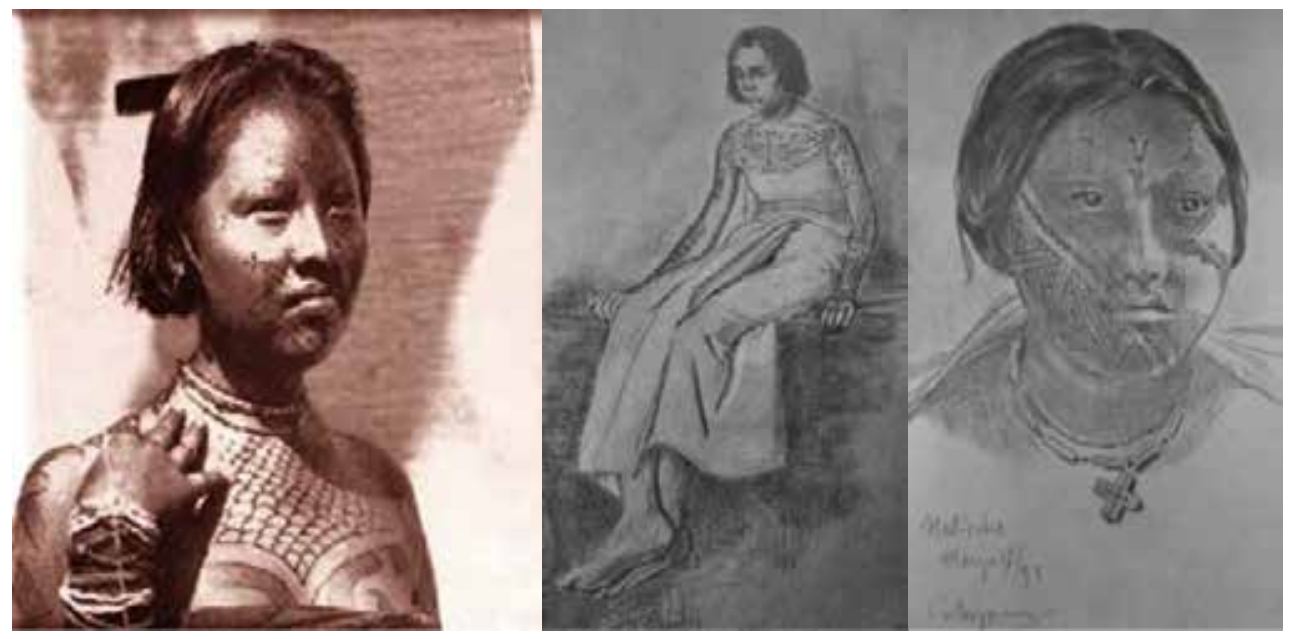

Figura 05 Índia Kadiwéu (rio Nabileque). Coleção Boggiani/1892, publ. Dr. R. Lehmann-Niitsche (In: Siqueira Jr; 1992, p.25); Figura 06 Jovem Caduveo (In: BOGGIANI, 1945, p.193) e Figura 07 Cunhada de Joãozinho (In: BOGGIANI, 1945, p.195).

Boggiani conclui o capítulo 5 de seu livro-diário, intitulado "O Nalique e os Caduveo", em que aparece a maior parte de suas descriçóes sobre a arte kadiwéu, com a afirmação de que "É uma verdadeira mania que têm os Caduveo pela ornamentação" (BOGGIANI, 1945, p. 229), e com a certeza de que "[...] muitos destes desenhos, repetidos constantemente na mesma ordem sobre a pessoa e sobre os objetos, tinham entre os Caduveo um significado preciso que não pode determinar bem" (COLINI apud BOGGIANI, 1945, p. 55-56).

\section{Claude Lévi-Strauss e os Cadiueu}

A beleza e a força dos Kadiwéu, descritas por Boggiani no final do século XIX, transformou-se sob o olhar de Lévi-Strauss: "Esses camponeses maltrapilhos, perdidos no fundo de seu pântano, ofereciam um espetáculo bem miserável, mas sua própria decadência tornava mais impressionante ainda a tenacidade com que tinham preservado certos traços do passado" (LÉVI-STRAUSS, 1996, p. 166).

Passando pela descrição do difícil acesso de seu grupo à aldeia Nalique, das casas feitas de palmas amareladas e sem paredes, das paisagens pantaneiras, da repulsa à procriação e das profundezas do contrato social feito entre os Mbaiá Guaikuru e suas divindades - Gonoenhodi e o Enganador, nas palavras de Lévi-Strauss -, em que os Kadiwéu tinham direito de oprimir e explorar outros povos, a arte é visivelmente o centro da reflexão do antropólogo belga sobre esse povo.

Apresentado como "traço extraordinário da cultura cadiueu" (LÉVI-STRAUSS, 1996, p. 173) sua arte gráfica é comparada às cartas de um ba- 
ralho europeu. Entendendo-a como parte de um dualismo que representa a forma como os Kadiwéu compreendem o mundo, Lévi-Strauss teoriza que, de um lado, há o estilo naturalista e representativo, desenvolvido por homens escultores e, de outro, o estilo não representativo, produzido pelas mulheres pintoras, em que "a forma da figura e do fundo se confundem, como um negativo" (LÉVI-STRAUSS, 1996, p. 179).

Os homens trançavam palha, teciam cintos com ela e com tecidos de algodáo, moldavam joias com moedas de níquel e de prata, além de desenhar animais como emas, cavalos, galinhas, jacarés, entre outros. As mulheres fabricavam cerâmicas com o barro do rio Pitoco e cacos moídos, decorando suas peças com os vernizes da resina derretida do pau santo, de cor preta, e do angico, de cor amarelada, finalizando suas produçóes com um pó branco de cinzas e giz, "para realçar as impressōes" (LÉVI-STRAUSS, 1996, p. 163).

Em suas pinturas de corpo e rosto - ainda mantidas, embora náo mais na forma de tatuagem - as mulheres pintavam umas às outras, improvisando desenhos, sem esboços, com o jenipapo e uma fina espátula de bambu. Repartindo as faces de suas modelos em quatro campos, desenvolviam pinturas assimétricas, porém equilibradas, sendo que entre quatrocentos desenhos recolhidos por Lévi-Strauss, nenhum se repetira, demonstrando seu vasto repertório.

Em particular, Lévi-Strauss observa que eram duas as formas de dar vazão a essa arte não representativa das mulheres. Uma forma geométrica e angular, indicada à pintura corporal e de cerâmica, e outra curvilínea e livre, voltada para pintura facial, em que ambas representariam seu status social.

Fazendo-se a pergunta "Para que serve a arte cadiueu?" (LÉVI-STRAUSS, 1996, p. 183), Lévi-Strauss responde ao dizer ser essa arte expressão de uma dupla oposiçáo. A primeira alude à morfologia social e hierárquica, de organizaçáo binária e simétrica, tendo em vista a relação de status entre cativos, feitos pelos Kadiwéu entre outros povos, indígenas ou náo indígenas, e senhores kadiwéu. A segunda se refere à morfologia natural e recíproca, de organização ternária e assimétrica, a separação entre natureza e cultura, animal e humano. 


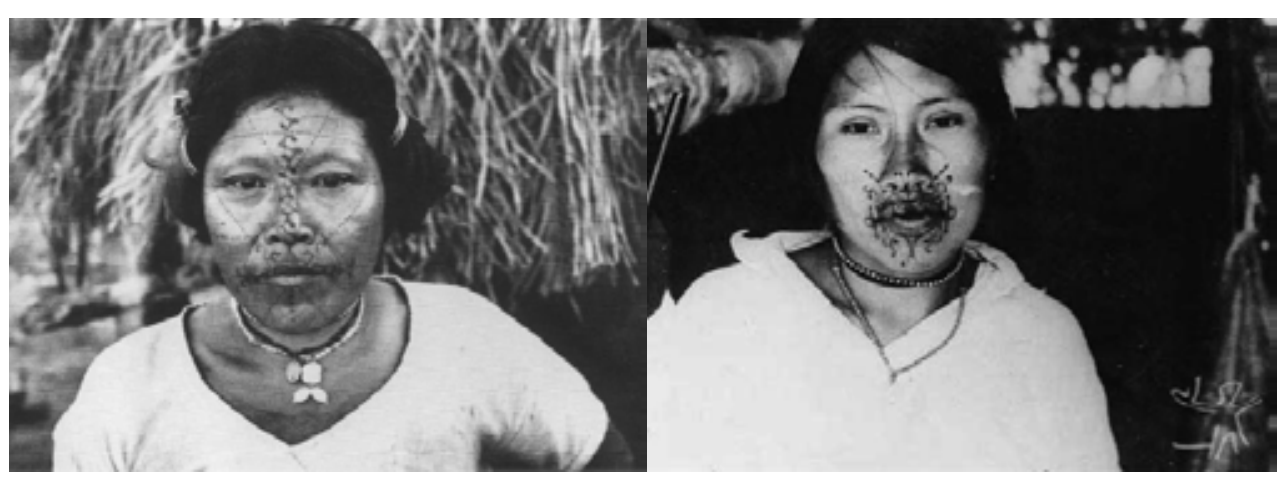

Figuras 08 e 09 Mulheres cadiueu de rosto pintado (In: LÉVI-STRAUSS, 1996, p.163).

Assim sendo, o dualismo é justificado na interpretação levistraussiana tanto pela sua função de objeto, servindo ao diálogo e ao duelo, quanto de representar um papel, o de ser arte dos Kadiwéu. Haveria, portanto, "uma vontade metassocial” por parte dos Kadiwéu (LÉVI-STRAUSS, 1996), de tornar a pintura uma das formas de expressão artísticas representativas de seu povo e, como tal, participante do jogo de contradiçôes específico do seu modo de vida. Tais formas paradoxais poderiam ser visualizadas na construção da noção de prestígio social entre os Kadiwéu, materializadas em muitas de suas práticas cotidianas.

Fosse por vontade, fosse por necessidade, cada casta tendia a se fechar em si mesma às custas da coesão do corpo social inteiro. Em especial, a endogamia das castas e a multiplicação das nuances da hierarquia podiam comprometer as possibilidades das uniōes convenientes às necessidades concretas $\mathrm{da}$ vida coletiva. Só assim se explica o paradoxo de uma sociedade relutante à procriação, e que, para se proteger dos riscos internos de casamentos desiguais, chega a praticar um racismo às avessas, que consiste na adoção sistemática de inimigos ou de estranhos. (LÉVI-STRAUSS, 1996, p. 184)

E mais, Lévi-Strauss constata que a beleza da arte kadiwéu não é averiguada pela originalidade dos motivos elementares que a compóem, mas sim pela combinação destes e pelo resultado final que produzem. Há uma série de complexidades, no "estilo cadiueu", em que os dualismos “[...] pintura e escultura, representação e abstração, ângulo e curva, geometria e arabesco, gargalo e bojo, simetria e assimetria, linha e superfície, contorno e motivo, peça e campo, figura e fundo" (LÉVI-STRAUSS, 1996, p. 182183) contrastam-se e complementam-se. Tal colocação do antropólogo, criador do método estruturalista, situa-se em um contexto em que não havia como investigar as interpretações dos próprios Kadiwéu em relação a esses motivos que produziam. 
Infelizmente, não me foi possível, nem a mim nem a meus sucessores, penetrar na teoria subjacente a essa estilística indígena: os informantes revelam alguns termos correspondendo aos motivos elementares, mas invocam a ignorância ou o esquecimento para tudo o que se refere às decoraçóes mais complexas. Seja porque, de fato, agem com base num saber empírico transmitido de geração em geração, seja porque fazem questão de guardar segredo a respeito dos arcanos de sua arte. (LÉVI-STRAUSS, 1996, p. 177)

Convencido de que aqueles eram os derradeiros momentos de expressão desse conhecimento artístico, Lévi-Strauss pôs-se a recolher desenhos em folhas de papel, destacando que poucas eram as mulheres a conservar o virtuosismo antigo, conhecido de livros anteriores, entre os quais o de Boggiani. O autor de Tristes trópicos relata, com surpresa, que havia recebido, em 1953, uma publicação ilustrada de um colega brasileiro - que julgamos ser a obra de Darcy Ribeiro - demonstrando que os motivos se mantinham os mesmos, até iguais, embora não houvesse tal continuidade nas peças de cerâmica, vistas por ele como em degenerescência. ${ }^{7}$

\section{Darcy Ribeiro e os Kadiwéu}

Darcy Ribeiro inicia suas consideraçóes com a afirmação de que "a arte, melhor que qualquer outro aspecto da cultura, exprime a experiência do povo que a produziu e somente dentro de sua configuração cultural ela pode ser plenamente compreendida e apreciada" (RIBEIRO, 1980, p. 258). Assim, demonstra sua adesão à sugestão levistraussiana.

Da mesma forma que Boggiani e Lévi-Strauss, que se julgavam os últimos a ter acesso à arte kadiwéu, tratando com pesar o caráter degenerativo da sociedade que visitavam, Ribeiro declara que "Os antigos ideais da cultura kadiwéu que honraram no homem a coragem, o herói, e na mulher o virtuosismo, a artista, continuam vivos apenas para elas" (RIBEIRO, 1980, p. 263). Ou seja, para o antropólogo brasileiro, os Kadiwéu estariam atravessando uma crise de redefiniçáo de valores advinda das mudanças que ocorreram em sua sociedade, em que, por exemplo, a hierarquia kadiwéu deixou de existir, sendo a arte daquele momento o "[...] produto de uma época de transição e, em grande parte, como esforço de conservação de um patrimônio inadequado aos novos caminhos que foram compelidos a tomar" (RIBEIRO, 1980, p. 259).

Por conseguinte, Ribeiro relata que muitas velhas kadiwéu queixavam-se e recordavam com carinho o passado, tempo em que "[...] eu nunca precisei 
rachar lenha, acender fogo e apanhar água, antigamente tinha cativa prá fazer tudo; eu só ficava era pintando o corpo, penteando o cabelo o dia todo até de noite, agora tenho que fazer tudo" (RIBEIRO, 1980, p. 262).

Para Ribeiro, apenas a cerâmica, ao contrário das outras expressões artísticas dos Kadiwéu - tais como trançados, entalhes na madeira e moldagens no metal, desenhos na cabaça, no couro, em tecidos, a música etc. - teria resistido ao longo dos anos, pelo incentivo financeiro do comércio com os brasileiros, propiciando certa preservação patrimonial.

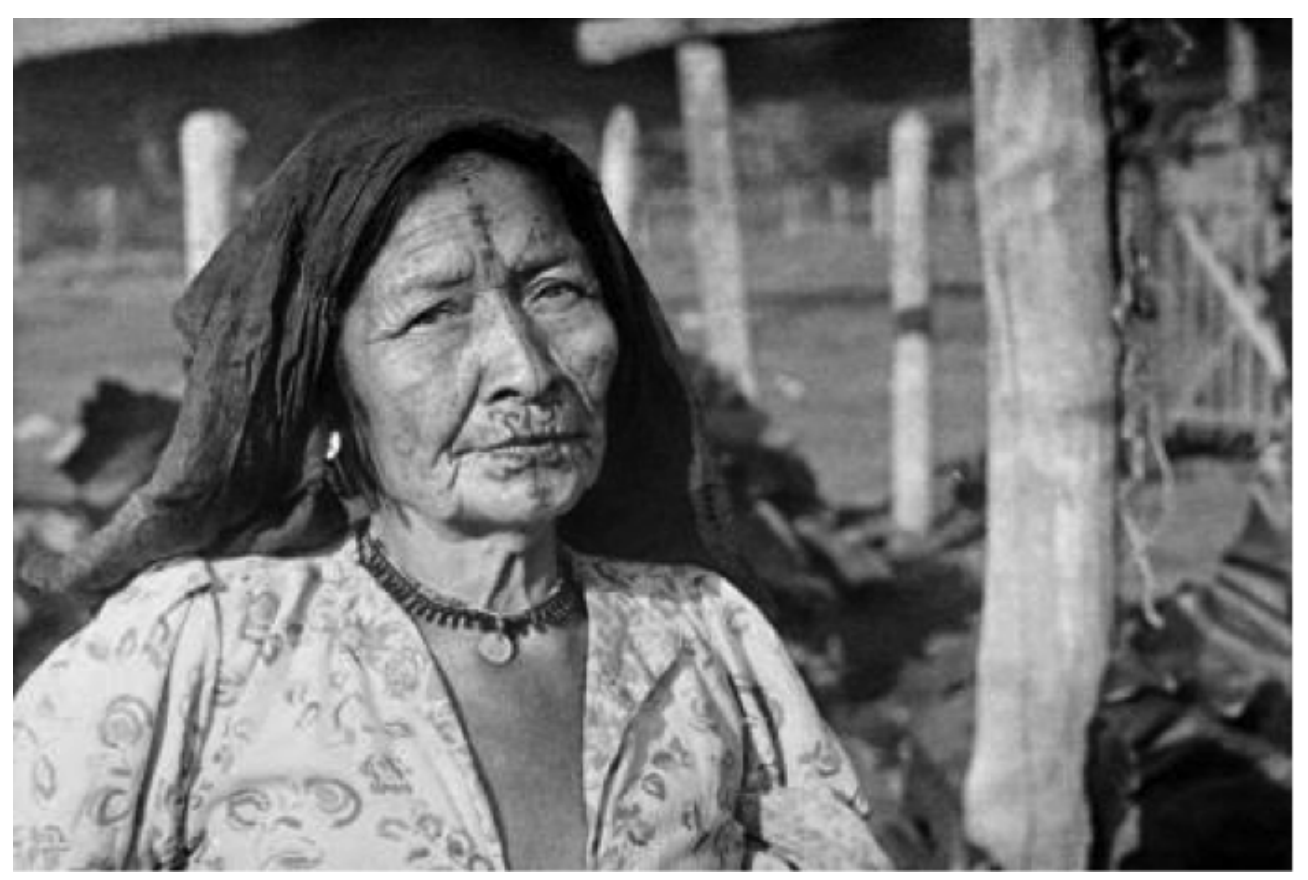

Figura 10 Anoã (In: RIBEIRO, 1980, p. 44).

A mistura destes dois argumentos, mercadológico e patrimonial, no sentido de bem cultural, tanto como justificativa de afirmação identitária quanto como característica salutar da redefinição de valores, é, para Darcy Ribeiro, a atual dualidade dos Kadiwéu nessa situação de crise e transformaçóes em que se encontram. O pesquisador questiona como teria sobrevivido a arte kadiwéu a) sem cativos e caracterizados como índios sedentários, estacionados em um local por muito tempo; b) enfrentando a competição com latarias industrializadas, em que seus potes de barro não são apreciados e seu valor ornamental já decaído.

Em 1947, Ribeiro sugere que a natureza dos desenhos era puramente formal, não simbólica ou figurativa, porém, houve um tempo em qu,e como os apelidos pessoais, os desenhos eram patrimônios de família, sendo uma ofensa grave seu uso indevido. Abaixo destacamos alguns nomes coletados por Ribeiro: 
[...] nadjéu, para as composiçôes de losangos; laui-léli ou náti-teuág, para os espiralados; agol-ho, para os círculos; noho-oi-lad, significando escalonados; áu-on-na, para os baseados em ângulos grossos; nikén-narnálat, para as linhas cruzadas e, ainda, io-tédi, para os estrelados e nídíg, para designar um padráo muito comum na cerâmica que consiste num triângulo irregular tendo a linha maior escalonada e um pequeno triângulo inscrito. (RIBEIRO, 1980, p. 271).

Além dessas figuras geométricas, Ribeiro cita nomes de padróes referentes às partes do corpo em que eram dispostas: "[...] ono-ké-dig, sobre o nariz; odipii-dena, sobre as maças; odá-tp-koli, na testa; io-kodrá-dígi, no colo; odo-ládi, nos braços" (RIBEIRO, 1980, p. 271).

Esses apontamentos fizeram com que Ribeiro concluísse que, sendo os nomes variantes e os padrôes com frequentes transformaçóes, os motivos modificam-se tanto em relaçáo à base tradicional cultural quanto em relação às mudanças ocasionadas pelo "novo" habitat, pela aculturaçáo e pela sobrevivência, via inserção no âmbito mercadológico. E conclui dizendo que "[...] os estilos não são estáticos, mas processos em contínua, embora lenta, transformação, que se faz por iniciativa de seus próprios cultores" (RIBEIRO, 1980, p. 268).

Após a ida de Ribeiro à capital kadiwéu, em meados de 1940, longo período se passou sem que houvesse antropólogos naquela terra indígena. O trabalho de Jaime Garcia Siqueira Junior (1993), 47 anos após a ida de Darcy Ribeiro aos Kadiwéu, inaugurou um novo fôlego de pesquisas acadêmicas em antropologia social entre os índios cavaleiros, sendo sucedido por Pechincha (1994), Lecznieski (2005), Petschelies (2013).

No presente momento, realizo pesquisa de doutoramento entre os Kadiwéu da aldeia Alves de Barros, próxima ao município de Bodoquena-MS, em que me proponho refletir sobre as relaçóes socioculturais que a arte possibilita aos Kadiwéu, seja como mediadora, seja como agente delas, como descrevo sucintamente a seguir.

\section{Padrão que conecta: alguns modos de relacionar kadiwéu}

No campo da arte como sistema de comunicação, ou seja, da arte como linguagem, da iconografia, existem duas formas de representação, a gráfica, vista como decorativa, e a figurativa, compreendida como representativa. A principal diferença entre elas é que a arte figurativa representaria os seres e objetos em formas reconhecíveis por aqueles que a contemplam, e 
a arte gráfica não. Ambas as colocaçóes, gráfica/decorativa ou figurativa/ representativa, que compóem a arte como um sistema de comunicaçáo, propóem a arte como algo que pode nos informar, ou seja, como partícipe da linguagem. ${ }^{9}$

Por outro lado, no âmbito da arte como agência, a pintura não somente pode nos informar/comunicar/significar algo, como pode fazer/afetar algo/ alguém. Isso não significa dizer que o objeto de arte independe do contexto social, pois "O objeto de arte é uma função da matriz relacional social na qual ele está inserido. Não tem nenhuma natureza 'intrínseca', independente do contexto relacional" (GELL, 1998, p. 7.Tradução minha). Para Gell (1998), a função da arte não é a de comunicar, informar ou representar algo do contexto sociocultural do qual advém, mas de participar da relação social como um agente em si. Ou seja, os objetos são como pessoas, pois são atores das relaçóes sociais em que estão envolvidos, possuem agência, e por isso lhes é concedido não somente "[...] o 'fazer', mas também qualquer modalidade de afetar alguém/algo" (GELL, 1998, p. 42).

Logo, a definição de arte como sistema de comunicação - gráfica/decorativa ou figurativa/representativa - é analisada como um dos modos de entender a arte. Gell não exclui totalmente essa via teórica, pois a introduz no conceito de índice; ${ }^{10}$ contudo, objetiva o alargamento das definiçóes sobre arte, para além da linguagem. Geralmente, os objetos de arte visuais são percebidos como objetos sobre os quais nos expressamos para lhes dar sentido, entendendo-os como parte da linguagem, e não uma língua em separado. Todavia, Gell teoriza que não é preciso encontrar algo para dizer sobre a arte, pois ela não faz parte da linguagem e, por essa razão, não constitui uma linguagem alternativa. ${ }^{11}$ Em resumo, para Gell a arte integra as relaçóes sociais para além do campo das linguagens - que expressam, representam, medeiam, que constroem sentidos. Sublinha, sobretudo, que a arte como índice é um agente relacional que pode "ser", e não somente "representar".

Isso posto, devemos ressaltar que o objetivo deste trabalho não é tratar da teoria antropológica sobre arte, mas sim do olhar kadiwéu sobre sua arte, buscando entender como eles consideram seus desenhos nas relaçóes que constroem, e, por isso, não nos alongaremos em tais referências.

Neste ponto, questionamo-nos, o que seria arte para os Kadiwéu? Sabemos que as mulheres kadiwéu, que se autointitulam artistas, nomeiam seus desenhos de duas formas, tanto como arte, para efeito de comunicação com os ecalai, ${ }^{12}$ quanto de godidigo (nosso desenho/escrita), enodagagi (nossa cerâmica), nadinagajegi (nosso traço/nossa pintura) (GRIFFITHS, 2002), para falar entre si. ${ }^{13}$ Como dizem os próprios Kadiwéu, sua arte é a pintura, "porque o barro sem a pintura não tem o mesmo valor" (Lenita 
Cruz, Aldeia Alves de Barros, 12/8/2014). Essa pintura é caracterizada pela reuniáo de padróes ou motivos, que têm variado com o passar dos anos. ${ }^{14}$

Foram coletados vinte nomes e descriçôes de padróes kadiwéu. Todavia, no presente artigo escolhemos tratar de quatro padrōes, os mais frequentes, que compóem relaçôes diferentes, no modo de pensar dos Kadiwéu. São eles: Niwécalad, Nawigicenig, Lawila, lageladinuinig ou dinoyé. Confundidos por muitos como sendo o mesmo motivo, nawigicenig e niwécalad são diferentes: de acordo com algumas mulheres mais velhas da aldeia, niwécalad é um desenho mais geometrizado que o nawigicenig, e simboliza os índios que antigamente subiam e desciam os morros da terra kadiwéu, nas cheias e secas do Pantanal.

Já o nawigicenig, segundo Olinda da Silva (Aldeia Alves de Barros, 17/01/2014), era um desenho que demonstrava a educação que a moça recebia de seus familiares, e que quando desenhado no dia da sua festa significava que ela era de boa família, obediente aos seus costumes e tradições, conhecedora do momento de falar ou não, e de como agir. Esse desenho ficava na altura da bochecha da moça (auicija), sendo desenhado nos dois lados do rosto, parecendo um freio de cavalo, pintados com a cor branca. ${ }^{15}$
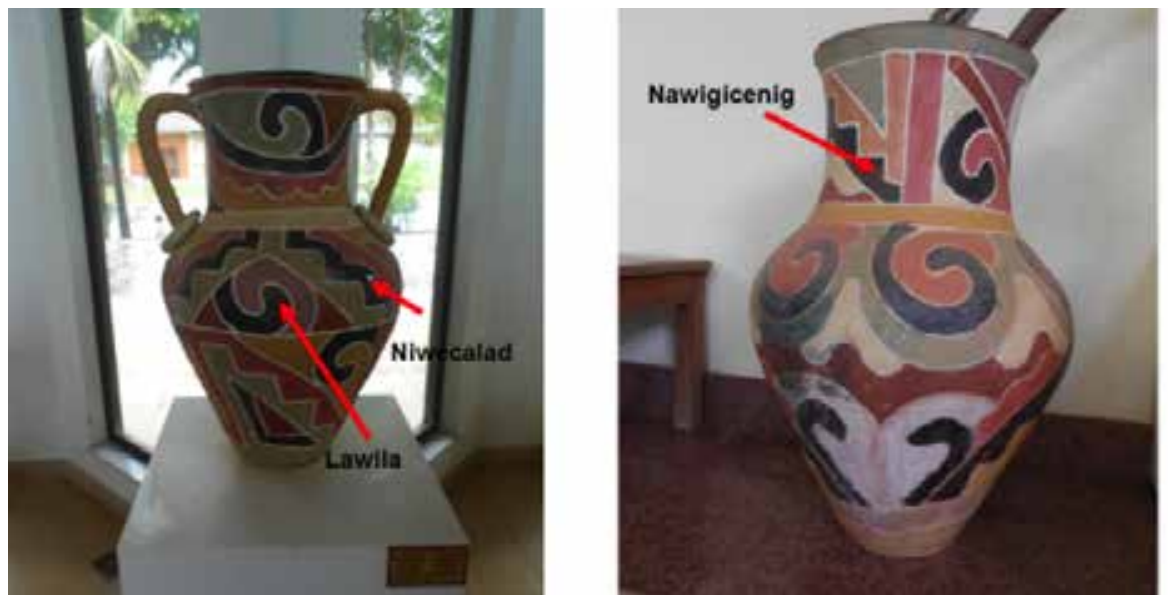

Figura 11 Desenhos Nawigicenig, Niwecalad e Lawila (Acervo Pessoal, Out/2015).

Com respeito ao lawila, Lenita Cruz (Aldeia Alves de Barros, 15/8/2014) afirma que tal desenho representaria o momento em que os índios antigos rodeavam os campos para vigiá-los contra a invasão de outros grupos, indígenas ou não, percorrendo toda a área pertencente aos Kadiwéu. Também traduzido como redemoinho, lawila pode significar uma roda de amigos que se reúnem para conversar, beber, comemorar, aparecendo no mito de nomeação das pessoas, como lawilawene (beira (lawila) da lagoa (wene)). Ambas as versões falam do caráter de "rodear" e não são vistas como contraditórias pelos integrantes da aldeia. 
Há uma terceira forma de compreensão do significado de lawila, como parte da linguagem dos cânticos, sendo que as mulheres idosas kadiwéu cantam porque "Quando a gente canta, diz que a gente reza" (PECHINCHA, 1994, p. 172). Nessa versão, lawila é um redemoinho feito pela ariranha (nagalaget) que mora no rio e que tenta raptar a moça no dia de sua festa. As jovens eram aconselhadas por Niwelanigi (personagem mítico) a náo comerem carne de ema, pois o perigo que envolvia comer carne de bicho era o de morrer ou o de "ficar como aquele bicho que você comeu" (PECHINCHA, 1994, p. 101). Por isso, diz Júlia Lange "[...] a moça não pode sair de casa, porque periga ser raptada pela ariranha, náo pode ver nenhum bicho, porque pode se transformar nele, não pode comer nem beber alimentos com gordura, porque pode se transformar em mulher faladeira" (Júlia Lange, Bodoquena, 14/9/2015), entre outras inúmeras proibições.

Além das variações do padrão escalonado, chamado de niwécalad por uns e nawigicenig por outros, há também transformaçóes do redemoinho, lawila. A primeira alteração consiste em acrescentar ao desenho lawila outra linha que o acompanha, formando um duplo lawila, e marcaçóes que parecem divisórias. Esse padrão se chama lageladinuinig ou dinoyé. Os Kadiwéu o traduzem como "a casa do rei" em português, explicando que é um desenho apotropaico feito para assustar ecalai. Contam que o rei, que é o capitão/cacique kadiwéu, está escondido na casa, centro do desenho, e que as marcaçôes do entorno são clâs da hierarquia kadiwéu, que dificultam a chegada de estranhos até a casa real e a protegem. Ele se posiciona no centro, sendo ao mesmo tempo protegido e protetor da comunidade.

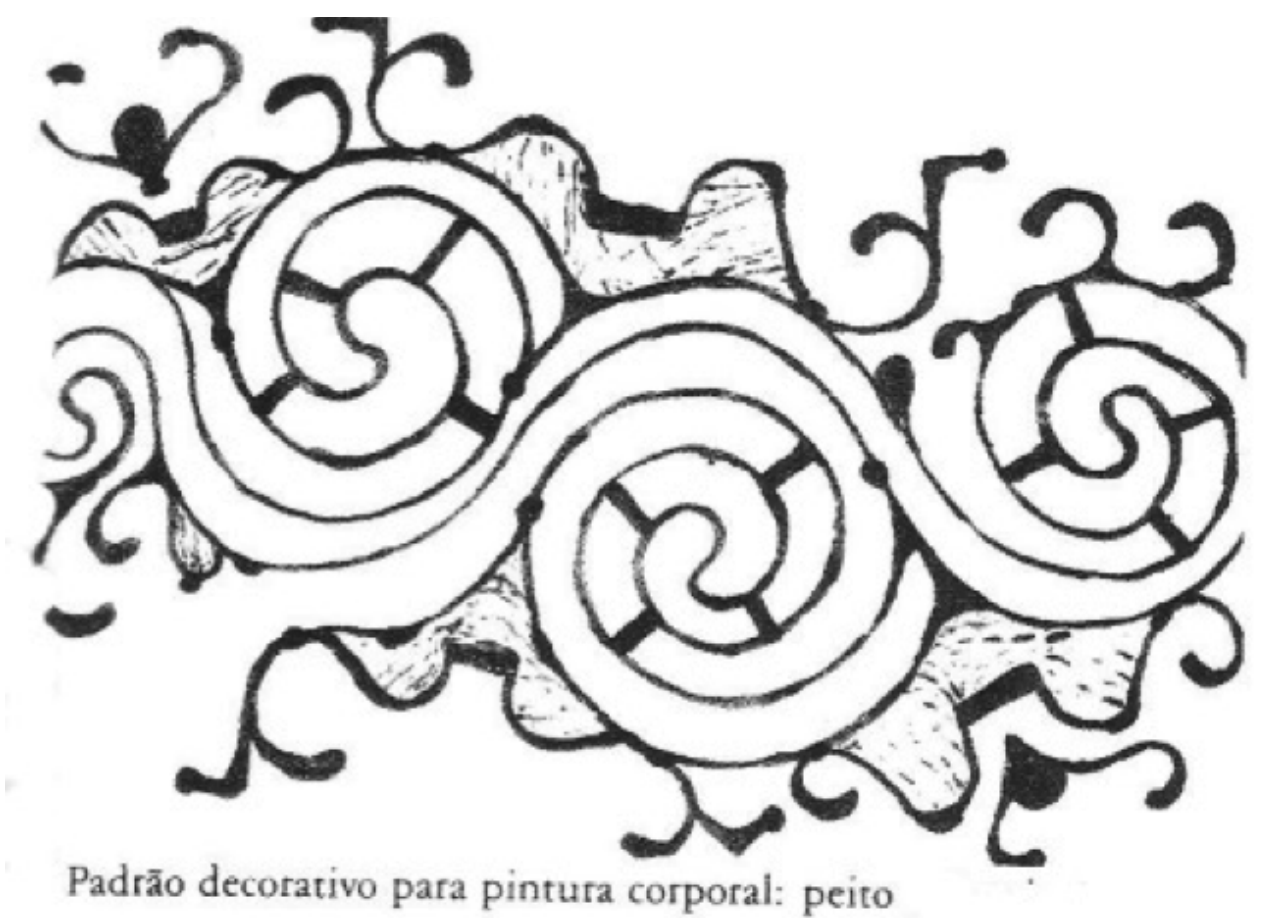

Figura 12 Desenho lageladinuinig ou dinoyé no centro (In: SIQUEIRA JR, 1993, p. 125). 
Esse desenho "mostra o índio que coloca medo no ecalai, pois quando sabe que o rei está na sua casa fica assustado, porque entende que se encontra em perigo, rodeado pela nação kadiwéu”, segundo $\mathrm{M}^{\mathrm{a}}$ Joana Pires (Aldeia Alves de Barros, Maria Joana Bernaldina Pires, 18/08/2014). Joana Baleia de Almeida (Aldeia Alves de Barros, 02/09/2014) conta que o assustar do desenho se refere, portanto, a uma estratégia de guerra de índios contra ecalai. Além de ser encontrado em couros, pode ser desenhado também em partes do corpo, como por exemplo, nos braços e peitoral, sugerindo a noção de proteção da casa (território/corpo) ou de lugar onde habita a força.

Júlia Lange nos explica ainda que, em geral, os desenhos kadiwéu não sáo derivados de nomes, como é o caso do lawila e da própria pessoa kadiwéu. Ou seja, não contam ou integram uma história, apenas comunicam, descrevem algo do cotidiano, e que nas histórias de seu avô, o senhor Mariano Rocha, os desenhos não tinham nomes, eram um aprendizado dos olhos, do copiar, de reprodução das figuras (Júlia Lange, Bodoquena, 18/9/2015).

Nos tempos antigos, a pintura informava sobre a hierarquia social do grupo, indicando aqueles chamados de Kadiwéu puros, com as faces cobertas somente na região da testa, e aqueles chamados de impuros ou cativos, desenhados no rosto e corpo todo. Hoje, a divisão senhor/cativo está diluída, quase inexistente, embora os Kadiwéu mais velhos queiram manter a distinção. No entanto, as pinturas que demarcam categorias sociais, como as de sexo e idade, estão presentes, como descrito acima. ${ }^{16}$

Assim, percebemos, nas descriçóes dos desenhos, que se trata de modos de se relacionar com o outro. Por exemplo, a pintura pode comunicar aos mortos a situaçáo social dos vivos, porque, quando os mortos procuram seus parentes, não os reconhecem via suas pinturas corporais e faciais, permitindo que o parente morto se desligue da vida que teve antes, além de também comunicar aos vivos a circunstância de luto daqueles que perderam seus parentes, pela ausência de pinturas.

Outro exemplo seria a pintura em crianças, que não devem ser pintadas porque ainda não entraram na vida social kadiwéu. A pintura é sinônimo de que a pessoa está pronta para encarar os percalços apresentados pela sociedade. Como consequência, quando alguém se pinta ou é pintado pela primeira vez, configura-se uma passagem entre a vida que é “interna”, protegida, para a que é "externa”, desprotegida, e isso está associado a uma série de práticas que ritualizam o momento liminar.

Os padróes também constituem uma forma de comunicação com os espíritos-divindades - pois é por meio deles que estes reconhecem o nidjenigi (xamã) - e de diferenciação do guerreiro, pois é a pintura que lhe dá a po- 
tencializaçáo dos sentimentos de raiva e crueldade necessários para matar alguém. E mais, os desenhos kadiwéu vestem seus corpos, diferenciando-os dos animais, que andam nus, e distinguindo-os dos indígenas que não são kadiwéu, mas que habitam seu território e que não costumam se pintar.

Destarte, por um lado poderíamos caracterizar a arte kadiwéu como iconográfica, sistema de comunicação, pois sua pintura informa a morfologia social e as categorias sociais, que distinguem as pessoas dentro da comunidade, por sexo, idade etc., bem como diferenciam os momentos rituais daqueles cotidianos. Por outro lado, poderíamos caracterizá-la como possuidora de agência, pois participa da relação social kadiwéu como um agente em si, afetando seus integrantes com o poder de deixá-los alegres e bonitos, invisíveis aos inimigos, visíveis às entidades que o xamá recebe. Ou seja, os desenhos participam das relaçóes sociais como seus mediadores e agentes. A pessoa múltipla que cada um pode ser, a depender da situaçáo relacional em que se posiciona, está colocada também no próprio desenho.

Sabemos que a pintura corporal não é mais táo frequente nos dias de hoje. Como, entáo, podemos afirmar que os desenhos continuam sendo sistema de comunicação e agência entre os Kadiwéu? Justificamos a persistência dessa arguiçáo, pois há na produção da cerâmica e no pintar-se em festas a continuidade dessas práticas.

$\mathrm{Na}$ cerâmica, as relaçóes de alteridade e autoridade que aparecem na pintura corporal também estão postas nas relaçôes geracionais, sexuais, políticas, espirituais etc., demonstrando a vivacidade das categorias antes relacionadas ao corpo, agora situadas na cerâmica. Como, por exemplo, no aprendizado das relaçóes comerciais transmitido da artista com mais tempo de mercado para aquela iniciante, nos conselhos a respeito da queima do barro e disposição dos desenhos na cerâmica, do seu moldar e da sua forma de negociaçáo (por encomenda ou por lei da oferta/procura), no reconhecimento dos desenhos de família dispostos nas cerâmicas, bem como das marcas (bigotaget) autorais feitas por algumas das artistas, do estranhamento das iniciativas de alguns homens que procuram fazer cerâmica ou de outros que são mestres reconhecidos e que são procurados para transmitirem seus saberes, entre inúmeras outras relaçóes possíveis. ${ }^{17}$

Hoje, as cerâmicas - único item que teria sobrevivido da arte kadiwéu, na leitura de Ribeiro (1980) - sáo muito diferentes daquelas vistas pelos clássicos. Em Boggiani, eram de apenas três cores (preto, branco e vermelho), extraídas de tipos diferentes de barro, sementes de frutas e pedras coloridas. Os desenhos eram aplicados na parte externa no pote, juntamente com miçangas, sem que as impressóes fossem marcadas pelo fio de caraguatá, dando relevo à peça, em sua maioria. 
As poucas fotos e a descrição de cerâmicas que aparecem na obra de Lévi-Strauss (1996) esclarecem que recebiam amarelo, além das cores já observadas anteriormente, e desenhos na parte externa, marcados pelo fio de caraguatá na maior parte das peças. Em Ribeiro (1980), outras cores ganham espaço (como o marrom, o rosa, os tons pastel), além de serem outras as formas dadas ao barro (vasos com moldagens distintas, peças ornitomorfas de outros bichos, aceites de encomendas de algo náo tradicionalmente produzido).
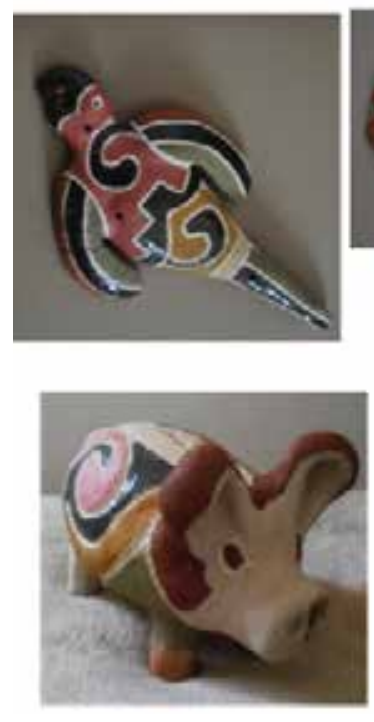
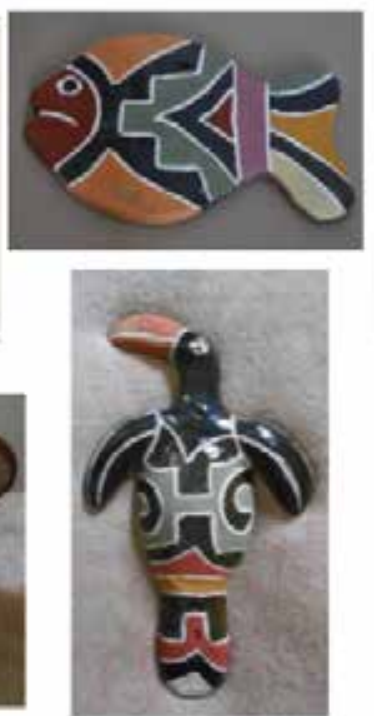
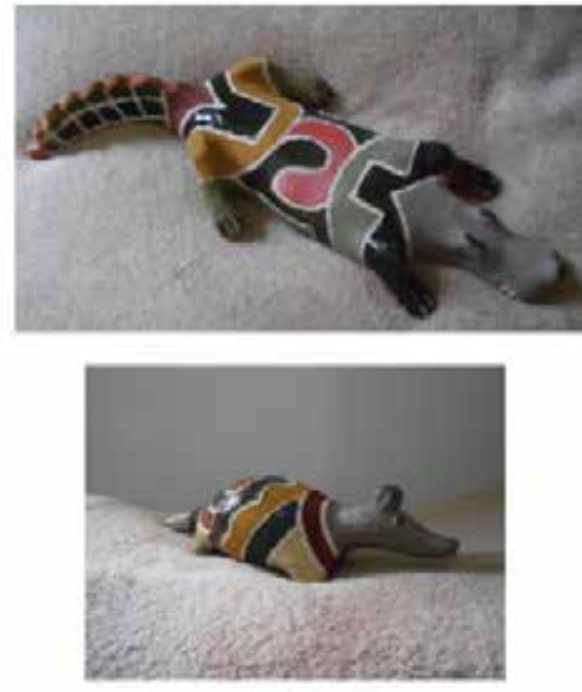

Figura 13 Peças Ornitomorfas (Acervo Pessoal, Set/2014).

Durante a minha estadia (2013-2015), pude observar a inserção das cores verde e lilás, prateado, dourado, cinza, entre outras, bem como a tentativa da pintura de cerâmica com tintas compradas (tintas de pintar casa, como chamam). Produzem sininhos, peças que formam conjuntos, máscaras, pintam em cabaças, em tecidos, explorando uma infinidade de possibilidades de divulgação e venda de sua arte, estando a produçáo ceramista atualmente muito ativa.

Portanto, a cerâmica, ao ser pintada, integra atualmente um conjunto de técnicas de relação vividas anteriormente pela pintura dos corpos, mantendo as diferenciaçóes, no modo como podem expressá-las. Para concluir esta seção, compreendemos que a pintura kadiwéu, assim como as relações sociais construídas por esse grupo, é de caráter posicional, sendo que ora integram a vertente da arte como sistema de comunicaçáo, ora interagem com a arte que é agência, armadilha, encantamento, pessoa distribuída (em lugares, objetos, relaçóes). Nesse sentido, seus padróes são expressóes do dualismo que compóe a pessoa kadiwéu, entre o duelo e o diálogo. 


\section{Conexões entre a antropologia e a arte kadiwéu}

Durante muitos anos, a antropologia que se encarrega de estudar as expressóes artísticas dos povos náo ocidentais denominou essas fabricaçóes de artefato produzido por primitivos, em contraposiçáo ao conceito de arte ocidental, produzida por civilizados. Historicamente, conceitua-se artefato como um objeto de uso utilitário e cotidiano, concepção que se volta mais para o nosso olhar e náo para o que realmente é (LAGROU, 2009). Há ainda a definição - datada do século XIX - de artefato como um espécime etnográfico, que é um "[...] processo de definição, de segmentação, de transposição a uma instituição pública ou privada” (VELTHEM, 2012, p. 53). ${ }^{18}$

Podemos dizer, atualmente, que a noção de arte se refere "[...] à capacidade consciente e intencional do homem de produzir objetos e ao conjunto de regras e técnicas que o pensamento usa para representar a realidade e agir sobre ela" (LAGROU, 2009, p. 68-69). Portanto, arte é um sistema técnico que promove uma transferência esquemática entre a produçáo do objeto artístico e o processo social. No caso das sociedades indígenas, esse sistema tem dois domínios, o ritual, que é político, e o de troca, que é cerimonial e comercial (GELL, 2005, p. 54-60). Ou seja, a arte é orientada "na direção da produção das consequências sociais que decorrem da produção desses objetos" (GELL, 2005, p. 45).

Considerando que a afirmação identitária de populaçóes nativas do mundo passa por questóes como a visibilidade, autenticidade e vitalidade destas, a incorporação e as maneiras de ver esses objetos, ou a inclusão da arte não ocidental em exposiçôes de arte contemporânea, têm promovido cada vez mais a atualidade do questionamento dessas categorias; mas também do papel do antropólogo. Este é também um colecionador de objetos etnográficos, detentor de coleções que muitas vezes são direcionadas a museus, inclusive como referentes de memória. Tendo em vista a classificação de Damy e Hatman (VELTHEM, 2012), as coleçóes brasileiras são de caráter variável, não apontam para uma sistemática nem para uma temática, na organização destes objetos.

Nas obras de Boggiani, Lévi-Strauss e Ribeiro há a preocupação de salvaguardar tanto os objetos produzidos pelos Kadiwéu quanto os desenhos realizados em seus corpos, porque esses autores alegavam o receio de que aquelas produçóes se perdessem no tempo, dada a falta de registro delas. Embora os clássicos demonstrem a necessidade de se debruçar mais sobre as artes kadiwéu, articulando possíveis interpretaçóes para elas e para os desenhos contidos nelas, não avançam no entendimento desses significados, do ponto de vista kadiwéu.

Em Boggiani (1945), a ideia de indeterminação dos significados dos desenhos, bem como a possibilidade de que estes sejam uma brecha para aquilo que é mantido em segredo - ou seja, sua filosofia de vida - são as 
respostas dadas pelo autor para tal problemática. A leitura que o explorador italiano faz é a de uma arte cujo significado não está ao seu alcance; contudo, tendo em vista o hábito kadiwéu de ornamentar pessoas, animais, objetos, fica sugerida a ideia de que há algo mais a ser explorado nessa arte. Boggiani náo está nem na vertente da arte como sistema de comunicaçáo, nem na da arte como agência, porque ainda discute se essa expressão artística seria ou não arte, fruto do contexto em que se situa.

Em Lévi-Strauss (1996), cuja teorização acerca dos significados da arte kadiwéu é a mais elaborada dentre as três, em nossa opinião, não há informaçóes a respeito daquilo que os próprios índios pensam sobre sua prática artística. Os Kadiwéu declaram ignorância ou esquecimento dos significados dos padróes, quando perguntados por Lévi-Strauss, sendo que, para o autor, essa arte seria ou um saber empírico ou um segredo que o grupo desejava preservar. Porém, ao definir que a arte kadiwéu é tanto representação de um papel, e aqui, sistema de comunicação, quanto função do objeto em servir ao duelo/diálogo, ou seja, agência do objeto na relaçáo, podemos compreender a vanguarda do pensamento levistraussiano.

Ribeiro (1980) chega a coletar nomes de padróes, visando explorar quais seriam seus significados pela perspectiva kadiwéu. Não obstante, a nomenclatura indicaria a natureza puramente formal dos desenhos, não simbólica ou figurativa. Ou seja, é pela visão de uma crise de valores que Ribeiro não segue nem a definição da arte kadiwéu como sistema de comunicação, nem da arte como agência. Todavia, a perspectiva da sobrevivência da cerâmica abre interpretações para a noção patrimonial e mercadológica da arte, agente de um resgate da cultura entre os Kadiwéu.

Isso posto, uma vez em campo, propusemo-nos a desafiar diversas linhas teórico-práticas dispostas nos livros de autores clássicos e contemporâneos que trataram da arte em suas etnografias indígenas. ${ }^{19}$ Os conflitos, que antes rondavam o tipo de pergunta que propúnhamos, após certo tempo transformaram-se em incertezas em relação àquilo que as mulheres kadiwéu sabiam de fato, ou queriam que nós soubéssemos.

Os vinte nomes coletados constituíam unanimidades entre as artistas da aldeia Alves de Barros, pois todas os conheciam e sabiam apontar nas cerâmicas ou nas imagens antigas de pinturas - corporais, faciais, de couro etc. - quais eram seus contornos. Quando perguntadas a respeito de seus significados, a mesma atitude citada por Lévi-Strauss acontecia: as respostas eram "não sabemos", "esquecemos", "não chegamos (a viver) nesse tempo antigo (ou com pessoas anciás)". Essa cena repetiu-se até que uma dessas mulheres resolveu falar; então uma reação coletiva foi desencadeada, em que quando perguntadas sobre o significado de um padráo recém descoberto, colocavam-se a debater as histórias de seus avós, dizendo se eram mentiras ou verdades o que suas parentes nos haviam dito. 
Ficou, assim, visível o tipo de relação de que a arte kadiwéu participa, a da preservação do "sistema índio" desse povo, em que esses objetos "condensam açóes, relaçóes, emoçóes e sentidos, porque é através dos artefatos que as pessoas agem, se relacionam, se produzem e existem no mundo" (LAGROU, 2009, p. 13).

Essas abduções dos objetos artísticos, ou seja, essa agência em conectar seres e mundos (GELL, 1992), é o que faz com que a arte exerça fascínio e poder mágico sobre nós. Ou seja, "é a dificuldade que tenho de abarcar mentalmente seu vir-a-ser como entes, em um mundo acessível a mim, por meio de um processo técnico que, uma vez que transcende meu entendimento, sou forçado a explicar como sendo mágico" (GELL, 2005, p. 50). Em sendo mágico, o artista torna-se um perito, um rádio transistor - e não criador - um técnico oculto, que promove a transformação entre o "fazer o que não existe do que existe, e fazer o que existe do que não existe" (GELL, 2005, p. 54).

Consequentemente, é preciso compreender as relações entre a produção da arte e o processo social, isso quer dizer visualizar o invisível, parte daquilo que indicamos acima. No caso de sociedades indígenas, trata-se de abranger uma arte que é contínua e não cumulativa, na qual o artista medeia essas relações, encontrando-se aí a dificuldade técnica do seu trabalho, e não na inovação de sua obra. Conduzindo, inclusive, à pacificação artística do inimigo, que é quando os grupos indígenas utilizam os artigos cativos, por exemplo, miçangas, na confecção de seus objetos (LAGROU, 2009).

Por fim, através da pesquisa sobre o potencial agencial e linguístico da arte kadiwéu, realizada via a leitura dos clássicos e da minha breve experiência de campo, concluímos que no diálogo com a antropologia, “[...] as diferenças não existem para serem respeitadas, ignoradas ou subsumidas, mas para servirem de isca aos sentimentos, de alimento para o pensamento" (LATOUR, 2002, p. 106).

\section{Notas}

1. E-mail: clavedera@yahoo.com.br.

2. Por exemplo, Getiadegodi (povo da montanha), Apacaxodegodegi (povo da região das emas) e os Cadigegodi (povo da regiâo do rio Cadigigi), de onde deriva o termo Kadiwéu, uma corruptela deste etnônimo (BASQUES, 2014, p. 506).

3. Jean-Baptiste Debret (1768-1848) foi um pintor, desenhista e professor francês. Integrante da Missão Artística Francesa (1817), publicou no livro Viagem pitoresca e histórica ao Brasil, entre os anos de 1834 e 1839, retratos do Brasil do século XIX. 
4. Muitos foram os autores que produziram registros sobre os índios Kadiwéu. Entre eles podemos citar como fontes históricas, dispondo entre parênteses os anos em que estiveram entre os Kadiwéu: Florian Paucke (17491767), José Sánchez Labrador (1760-1770), Francisco Mendez (1772), Francisco Rodrigues do Prado (1839), Félix de Azara (1809), Francis Castelnau (1850), Ricardo Franco de Almeida Serra (1845) e Emílio Rivasseau (1880). Além destes, Guido Boggiani $(1892,1897)$, autor da obra Os Cadiuéus (1945) e os antropólogos Claude Lévi-Strauss (1935), com a obra Tristes trópicos (1955) e Darcy Ribeiro (1940/1944), autor de Kadiwéu: ensaios etnológicos sobre o saber, o azar e a beleza (1980), contribuíram para a exposição e teorização deste grupo indígena.

5. Os meses de trabalho de campo (jul./2013, jan./2014, ago./2014, set./2014, out./2014, set./2015 e out./2015) são parte imprescindível do processo de doutoramento no Programa de Pós-Graduação em Antropologia Social (PPGAS/USP), iniciado em 2013 e com previsão de término para 2016.

6. É interessante notar que houve um intervalo de 39 anos entre Boggiani e Lévi-Strauss, e de 13 anos entre Lévi-Strauss e Ribeiro, no que diz respeito aos respectivos encontros desses autores com os Kadiwéu. Contudo, no tocante às suas publicaçóes, percebemos um descompasso temporal, pois entre Boggiani e Lévi-Strauss há um distanciamento de 61 anos, sendo que embora Ribeiro tenha visitado os Kadiwéu após Lévi-Strauss, a publicação de seu livro ocorre cinco anos antes.

7. Antes de partirmos para a análise feita por Ribeiro, ressaltamos que sabemos da existência de outros textos de Lévi-Strauss em que há referências aos Kadiwéu, por exemplo, em Antropologia estrutural (v. 1 - 1986) e em A via das máscaras (1981). Contudo, nos propusemos aqui a reflexão com relação às obras principais sobre Kadiwéu, escolhendo um texto de cada autor, por se tratar de um artigo.

8. Sabemos das inúmeras problematizaçóes da noção de arte, na antropologia da arte (vide: GELL, 1998, 2001a, 2001b, 2001c, 2005; INGOLD, 1993; MORPHY, 1994; LAYTON, 1991; LAGROU, 2009; WARBURG, 2003; FREEDBERG, 1989; MITCHELL, 2005; entre outros). Contudo, interessados em abordar futuramente a equivocidade tradutória (VIVEIROS DE CASTRO, 2004) que esse conceito promove entre os Kadiwéu, nos permitimos mantê-lo aqui, por questóes contextuais.

9. Um exemplo da arte como sistema de comunicação encontra-se na análise iconográfica da pintura Wajápi. Para Gallois (1992), a pintura Wajãpi informa sobre os mortos e os inimigos, em vez de informar sobre suas categorias sociais ou morfologia social, outro caminho possível. Por meio da análise da decoração corporal Wajāpi, num sentido coletivo, e dos padróes 
gráficos, num sentido individual, é possível captar uma eficácia simbólica do modo como se aproximar ou se afastar dos vivos em relação aos mortos e dos amigos em relação aos inimigos, de forma controlada, pelo conhecimento transmitido via pintura.

10. Índices são "[...] entidades materiais que motivam inferências, respostas ou interpretaçôes" (GELL, 1998, p. 13). Deste modo, se motivam interpretaçôes, podem participar também da linguagem. Por exemplo, em situaçóes de apreciação da arte, Gell define que "o índice material (visível, físico, 'coisa') permite uma operação cognitiva particular" (GELL, 1998, p. 13), chamada de abdução da agência. Abdução é uma tentativa de traçar um sistema de regras de significação que permite ao signo adquirir um significado. É definida ainda como esquema de inferência ou índices de signos (GELL, 1998, p.14-15).

11. Nesse ínterim, o grafismo indígena, considerado uma linguagem alternativa, não representativa, de simbolização de algo, poderia ser considerado, na vertente aqui exposta como gelliana, uma técnica de memória. Comum a alguns grupos, os padróes amazônicos de pintura são assim interpretados por Pierre Dèléage (2012), cuja análise destaca na memorização uma referência a um nome ou lugar clânico e, assim, um modo visual de relação com o outro. Situamos no conceito de quimera (SEVERI, 2013) um modelo desse segundo grupo teórico na antropologia da arte. Quimera é toda imagem múltipla, em que índices visuais de seres diferentes provocam uma imagem de suas presenças ao mesmo tempo. Ou seja, é uma “[...] representação plural onde o que é dado a ver apela necessariamente à interpretação do que é o implícito" (SEVERI, 2013, p. 12). Para Lagrou (2013) esse processo intensificaria a eficácia da imagem, pois mobilizaria suas partes invisíveis, além das visíveis. Portanto, haveria um movimento pendular entre as relações que se mostram como interioridade/cognição/percepção (intencionalidade e agência) e como exterioridade/(des)figuação (fisicalidade), sendo que, por exemplo, o xamã transitaria entre as manifestaçóes dos seres, causando a tal fluidez das formas.

12. Os Kadiwéu designam os não índios como ecalai, que significa "civilizado", sendo usado também para significar "dono", "patrão", ou ainda "nosso patrâo" (GRIFFITHS, 2002, p. 40).

13. Aqui me inspiro em Velthem (2009) para compreender a denominação godidigo "nosso desenho" pelos Kadiwéu. Ela explica que: "Como as partes do corpo humano que não podem ser descritas sem pronome possessivo, as coisas, feitas por esse mesmo corpo, enquadram-se nessa perspectiva. $\mathrm{O}$ vocábulo ëtiparé, 'meus feitos', circunscreve a totalidade do que é produzido através do trabalho manual individual, masculino ou feminino, segundo princípios que são eminentemente wayana” (VELTHEM, 2009, p. 217). 
14. É perceptível a transformação da pintura na cerâmica kadiwéu. Pude observar a diferença entre o acervo de cerâmicas kadiwéu do Museu do Índio (Rio de Janeiro), fruto da doação do antropólogo Darcy Ribeiro, material coletado por ele em meados dos anos 1940 e aquilo que podemos observar atualmente, em que a cerâmica assume novas cores, padrôes e formas, demonstrando a atualização constante das peças, embora integrantes de uma mesma tradição artística.

15. Atualmente, a pintura para a festa da moça, que é celebrada, quando esta completa quinze anos, na igreja em que a sua família congrega, é feita com batom e outras maquiagens. É também típico dessa festa um grande bolo, a decoração com bexigas rosa e muito refrigerante.

16. Na dissertação de Padilha (1996) há uma análise da arte kadiwéu como elemento-chave para a compreensáo daquilo que fundamenta o modo de vida desse grupo, relacionado à aceitação e a recusa do outro. Portanto, para Padilha, a arte kadiwéu seria "a concretude ou a marca da etnia" (PADILHA, 1996. p. 127). Nos livros Kadiwéu: senhores da guerra, senhoras da arte (volumes I e II), há uma compilação de trabalhos acadêmicos de diversas áreas sobre os Kadiwéu, no entanto, no quesito arte, poucas são as contribuições, para além daquilo que já descrevemos aqui, por meio das obras de Boggiani (1945), Lévi-Strauss (1996) e Ribeiro (1980).

17. Destacamos aqui o trabalho de Vânia Graziato (2008), que, por meio dos conceitos de persistência e tradição oral, construiu uma análise das transformaçóes dos processos de produção da cerâmica kadiwéu, dando enfoque particular para a mudança de habitat do grupo, o que incentivou as artesâs kadiwéu a inserir novas matérias-primas, bem como a renovação do olhar sobre o repertório gráfico antigo, do século XIX até o século XXI. É interessante observar como Graziato faz dialogar com a sua produção, enquanto artista plástica, a produçáo kadiwéu, estudada pela autora entre 2000 e 2005.

18. Isso ocorreu porque a antropologia social assumiu durante anos uma posição de filistinismo metodológico, que significa "assumir uma atitude de indiferença resoluta no que diz respeito ao valor estético das obras de arte - o valor estético que elas possuem, seja do ponto de vista local ou do esteticismo universal" (GELL, 2005, p. 44). Podemos observar essa separação entre arte moderna e arte primitiva, na visão patrimonial desses objetos etnográficos, em que seus valores ameríndio, institucional, arqueológico, etnográfico e paisagístico são representados nos museus, inclusive com sincretismos de valores, mas sua importância artística não (VELTHEM, 2012).

19. Exemplos disso são: Alfred Gell (1993, 1998, 1999, 2001 e 2005), Els Lagrou (2007, 2009), Lagrou e Severi (2014), Velthem (1998, 2012), Price (2000), Freedberg (1989), Latour (2002), Mitchell (2005), Vidal (1992), 
Ingold (1993), Vernant (1973), Layton (1991), Warburg (2003), Didi-Huberman (2002), Geertz (1997), Boas (2014), Barcelos Neto (2008), Overing (1991), Olschewski (2013), Strathern (1998, 2006), Küchler (2002), Cesarino (2011, 2012), Cesarino e Carneiro da Cunha (2014), Guerreiro Jr. (2012), entre muitas outras referências bibliográficas.

\section{Referências bibliográficas}

BARCELOS NETO, Aristóteles. Apapaatai: rituais de máscaras no Xingu. São Paulo: Edusp/Fapesp, 2008.

BOAS, Franz. Arte Primitiva. Trad. Fábio Ribeiro. Petrópolis: Vozes, 2014.

BOGGIANI, Guido. Os Caduveo. [1.ed.: 1894] São Paulo: Livraria Martins Editora, 1945.

CESARINO, Pedro. Oniska: poética do xamanismo na Amazônia. São Paulo: Perspectiva/Fapesp, 2011.

- A escrita e os corpos desenhados: transformações do conhecimento xamanístico entre os Marubo. Revista de Antropologia, São Paulo, USP, v. 55 n. 1, p.75-136. 2012.

CESARINO, Pedro; CARNEIRO DA CUNHA, Manuela. (Org.) Politicas culturais e povos indígenas. 1.ed. São Paulo: Cultura Acadêmica, 2014.

CHALUMEAU, Jean-Luc. As teorias da arte: filosofia, crítica e história da arte de Platão aos nossos dias. Lisboa: Instituto Piaget, 1997.

CLIFFORD, James. Histories of the Tribal and the Modern. In: The Predicament of Culture. Cambridge: Harvard University Press, 1988. p. 189-214.

COOTE, Jeremy. "Marvels of Everyday Vision": the anthropology of aesthetics and the cattle-keeping Nilotes. In: COOTE, J.; SHELTON, A. Anthropology, Art, Aesthetics. Oxford: Clarendon Press, 1992. p. 245-275.

DÈLÈAGE, Pierre. Les Répertoires graphiques amazoniens. Journal de la société des américanistes, t. 93, n. 1, p.2-22. 2007. Disponível em: <http://jsa.revues. org/6693>. Acessado em: 30/03/2015.

DIDI-HUBERMAN, Georges. L'Image survivante. Histoire de l'art et temps des fantômes selon Aby Warburg. Paris: Les Éditions de Minuit, 2002.

FOSTER, Hal. The "Primitive" Unconscious of Modern Art. In: October 34, 1985. p. 45-70. FREEDBERG, David. The Power of Images. Chicago/London: The University of Chicago Press, 1989.

FREUNDT, Erich. Indios de Mato Grosso. Introdução de Herbert Baldus. São Paulo: Melhoramentos, 1946.33p.

GALLOIS, Dominique Tilkin. Arte iconográfica Waiãpi. In: Grafismo indígena: estudos de antropologia estética. São Paulo: Studio Nobel/Editora da Universidade de São Paulo/FAPESP, 1992. p. 209-230.

GEERTZ, Clifford. O saber local: novos ensaios em antropologia interpretativa. (1. 
ed.: 1983) Trad. Vera Mello Joscelyne. Petrópolis: Vozes, 1997. 366p.

GELL, Alfred. Wrapping in Images: tattooing in Polynesia. Oxford: Clarendon Press, 1993. . Art and Agency. Oxford: Clarendon Press, 1998. . The Art of Anthropology. Londres: The Athlone Press, 1999. . A rede de Vogel: armadilhas como obras de arte e obras de arte como armadilhas. Arte e Ensaios, n. 8, p.174-191. 2001a. On Coote's "Marvels of Everyday Vision". In: The Art of Anthropology (Essays and Diagrams). London: The Athlone Press, 2001b. p.215-232. Strathernograms. In: The Art of Anthropology (Essays and Diagrams). London: The Athlone Press, 2001c. p.29-76. . A tecnologia do encanto e o encanto da tecnologia. Trad. Jason Campelo. Concinnitas, ano 6, v.1, n. 8. 2005.

GOW, Peter. A geometria do corpo. In: Novaes, Adauto. (Org.). A outra margem do Ocidente. São Paulo: Companhia das Letras, 1999. p. 299-317.

GRAZIATO, Vânia Perrotti Pires. Cerâmica Kadiwéu: processos, transformações, traduçôes. Uma leitura do percurso da cerâmica kadiwéu do século XIX ao XXI. São Paulo, 2008. Dissertação (Poéticas Visuais) - Escola de Comunicação e de Artes, Universidade de Sáo Paulo.

GREENBERG, Clement. O juízo estético. In: Estética doméstica. São Paulo: Cosac Naify, 2002. p. 47-65.

GUERREIRO JUNIOR, Antonio Roberto. Ancestrais e suas sombras - uma etnografia da chefia kalapalo e seu ritual mortuário. Brasília, 2012. Tese (Doutorado em Antropologia Social) - Instituto de Ciências Sociais, Universidade de Brasília.

GRIFFITHS, G. Dicionário da Lingua Kadiwéu. Kadiwéu-Português. Português-Kadiwéu. Cuiabá: Sociedade Internacional de Linguística (SIL), 2002.

HANKE, W. Cadivéns y terenos. Arquivos do Museu Paranaense, Curitiba, v. 2, p. 79-86, jul. 1942.

INGOLD, Tim (ed). Aesthetics is a Cross-Cultural Category. In: Key Debates in Anthropology. London: Routledge, 1993. p.249-294.

JOSÉ DA SILVA, G. A construçâo física, social e simbólica da Reserva Indígena Kadiwéu: memória, identidade e história. Dourados, 2004. Dissertação (História) - Centro de Ciências Humanas e Sociais - Universidade Federal de Mato Grosso do Sul.

. Kadiwéu: senhoras da arte, senhores da guerra. (v. I). Curitiba: Editora CRV, 2011.

JOSÉ DA SILVA, G; KOK, Maria da Glória Porto. Kadiwéu: senhoras da arte, senhores da guerra. (v. II). Curitiba: Editora CRV, 2014.

KÜCHLER, Suzanne. Malanggan. Oxford: Berg, 2002.

HARAWAY, Donna. Manifesto ciborgue. In: Antropologia do ciborgue. Belo Ho- 
rizonte: Autêntica Editora, 2009. p. 33-118.

LAGROU, E.; SEVERI, C. Quimeras em diálogo: grafismo e figuração na arte indígena (v. 1). 1.ed. Rio de Janeiro: 7Letras, 2014.

LAGROU, Els. A fluidez da forma: arte, alteridade e agência em uma sociedade amazônica (Kaxinawa, Acre). Rio de Janeiro: TopBooks, 2007. 565p.

. Arte indígena no Brasil: agência, alteridade e relação. Belo Horizonte: C/ Arte, 2009.

LATOUR, Bruno. Reflexão sobre o culto moderno dos deuses fe(i)tiches. Bauru: Edusc, 2002.

O que é iconoclash? Ou, há um mundo além das guerras de imagem? Horizontes Antropológicos, n. 29, p. 111-150. 2008.

LAYTON, Robert. The Anthropology of Art. Cambridge: Cambridge University Press, 1991

LECZNIESKI, Lisiane Koller. Estranhos laços: predação e cuidado entre os Kadiwéu. Florianópolis, 2005. Tese (Coordenadoria do curso de Antropologia) - Universidade Federal de Santa Catarina, Florianópolis.

Memória e história entre índios brasileiros: os Kadiwéu e seus etnógrafos Darcy Ribeiro e Guido Boggiani. História Revista, n. 5 (1/2), p. 151-163, jan./dez. 2000. Disponível em: <http://www.revistas.ufg.br/index.php/historia/article/viewFile/10594/7052> Acessado em: 3/5/2014.

LÉVI-STRAUSS, Claude. Tristes trópicos. [1 1 $^{\mathrm{a}}$ Ed.1955] Trad. Rosa Freire d'Aguiar. São Paulo: Companhia das Letras, 1996.

- O suplício do Papai Noel. Trad. Denise Bottmann. São Paulo: Cosac Naify, 2008.

. A via das máscaras. Lisboa: Editorial Presença, 1981.

. O desdobramento da representação nas artes da Ásia e da América. In: Antropologia estrutural (v. 1). Rio de Janeiro: Tempo brasileiro, 1985. p. 279305.

MITCHELL, W. J. T. What do Pictures Want? Chicago: The University of Chicago Press, 2005.

MORPHY, Howard. The Anthropology of Art. In: Ingold, Tim. (Ed.). Companion Encyclopaedia of Anthropology. London/Nova York: Routledge, 1994. p. 648-685.

OLSCHEWSKI, Luisa Elvira Belaunde. Processos criativos na pintura visionária xamânica da Amazônia peruana. 37a ANPOCS, ST 35, 2013.

OVERING, Joanna. A estética da produção: o senso da comunidade entre os Cubeo e os Piaroa. Revista de Antropologia, São Paulo, Universidade de São Paulo, p. 7-34. 1991.

PADILHA, Solange. A arte como trama do mundo: corpo, grafismo e cerâmica kadiwéu. São Paulo, 1996. 218f. Dissertação (Ciências Sociais) - Faculdade de Ciências Sociais, Pontifícia Universidade Católica de São Paulo.

PASSETI, Dorothea Voegeli. Lévi-Strauss, antropologia e arte: minúsculo - inco- 
mensurável. São Paulo: Edusp/Educ, 2008.

PECHINCHA, Mônica Thereza Soares. Histórias de admirar: mito, rito e história kadiwéu. Brasília, 1994. 202f. Dissertação - Instituto de Ciências Sociais, Universidade de Brasília.

.Memória e história entre índios brasileiros: os Kadiwéu e seus etnógrafos Darcy Ribeiro e Guido Boggiani. História Revista, Goiânia, v. 5, n. 1/2, p. 151-163, jan./dez. 2000.

PRICE, Sally. Arte primitiva em centros civilizados. Trad. Inês Alfano. Rio de Janeiro: Editora UFRJ, 2000.

RIBEIRO, Darcy. [1ª Ed.1976] Kadiwéu: ensaios etnológicos sobre o saber, o azar e a beleza. Petrópolis: Vozes, 1980.

SANCHEZ-LABRADOR, Jose. Paraguay Catolico. Buenos Aires : Coni Hermanos, 1910.

SEVERI, Carlo. O espaço quimérico. Percepção e projeção nos atos do olhar. In: LAGROU, E.; SEVERI, C. Quimeras em diálogo: grafismo e figuração na arte indígena (v. 1). 1.ed. Rio de Janeiro: 7Letras, 2014.

SIQUEIRA JUNIOR, Jaime. Esta terra custou o sangue de nossos avós: a construção do tempo e espaço kadiwéu. São Paulo, 1993. Dissertação - Faculdade de Filosofia, Letras e Ciências Humanas, Universidade de Sáo Paulo.

Arte e técnicas kadiwéu. São Paulo: Secretaria Municipal de Cultura, 1992. $125 \mathrm{p}$.

STRATHERN, Marilyn. Novas formas econômicas: um relato das terras altas da Papua - Nova Guiné. Mana, 4 (1), abr.1998.

O gênero da dádiva: problemas com mulheres e problemas com a sociedade na Melanésia. Trad. André Villalobos. Campinas: Editora da Unicamp, 2006.

- Fora de contexto: as ficçôes persuasivas da antropologia. São Paulo: Terceiro Nome, 2013. 160p.

TAYLOR, Anne-Christine. Wives, Pets, and Affines: marriage among the Jivaro. In: Rival, L.; Whitehead, N. (Ed.). Beyond the Visible and the Material: the amerindianization of society in the work of Peter Rivière. Oxford: Oxford University Press, 2001.

O corpo da alma e seus estados: uma perspectiva amazônica sobre a natureza de ser-se humano. Revista Cadernos de Campo, São Paulo, n. 21, p. 213-228. 2012.

VELTHEM, Lúcia Hussak Van. O belo é a fera. A estética da produção e da predação entre os Wayana. São Paulo, 1995. Tese (Doutorado em Antropologia Social) - Faculdade de Filosofia, Letras e Ciências Sociais, Universidade de São Paulo/ Lisboa: Assírio \& Alvim, Museu Nacional de Etnologia, 2003.

. Mulheres de cera, argila e arumã: princípios criativos e fabricação material entre os Wayana. In: Mana, Rio de Janeiro, n. 15(1), p. 213-236. 2009. 
O objeto etnográfico é irredutivel? Pistas sobre novos sentidos e análises. Boletim do Museu Emilio Goeldi - Pará. Ciências Humanas; Belém, v. 7, n. 1, p. 51-66, jan./abr. 2012.

VERNANT, Jean-Pierre. Figuração invisível e categoria psicológica do "duplo": o kolossós. In: Mito e pensamento entre os Gregos. São Paulo: Difel/Edusp, 1973. p. 263-277.

VIDAL, Lux. (Org.) Grafismo indígena: estudos de antropologia estética. São Paulo: Studio Nobel/Editora da Universidade de São Paulo/FAPESP, 1992.

VIVEIROS DE CASTRO, Eduardo. O nativo relativo. Mana [online], Rio de Janeiro, v. 8, n. 1, p. 113-148. 2002. Disponível em: <http://dx.doi. org/10.1590/S0104-93132002000100005>.

. A floresta de cristal: notas sobre a ontologia dos espíritos amazônicos. Cadernos de Campo, São Paulo, n. 14/15, p. 319-339. 2006.

Perspectival Anthropology and the Method of Controlled Equivocation. In: Tipiti: Journal of the Society for the Anthropology of Lowland South America, v. 2, n. 1. 2004. Disponível em: <http://digitalcommons. trinity.edu/tipiti/vol2/iss 1/1>.

WARBURG, Aby. Le Rituel du serpent. Paris: Macula, 2003.

\section{Referências filmográficas}

BODANSKY, Jorge; MENGET, Patrick. (Dir.). À propos de tristes tropiques. Vídeo Cor, U-Matic, 50 min., Prod.: Yves Billon; Les Filmes du Village, 1991.

\section{autora Maria Raquel da Cruz Duran}

Graduada em Ciências Sociais (UNESP/Campus Araraquara), mestre em Ciência, Tecnologia e Sociedade (UFSCar/São Carlos) e doutoranda no Programa de Pós-Graduação em Antropologia Social, na Universidade de São Paulo (USP), sob a orientação da Profa. Dra. Marta Amoroso. 